\title{
Exogenous Glutathione Alleviates Cadmium Toxicity in Wheat by Influencing the Absorption and Translocation of Cadmium
}

\author{
Ge-Zi Li · Shi-Juan Chen ${ }^{1}$ · Na-Ying $\mathrm{Li}^{1}$ · Ying-Ying Wang ${ }^{1}$. Guo-Zhang Kang ${ }^{1,2}$
}

Received: 11 November 2020 / Accepted: 3 June 2021 / Published online: 10 June 2021

(c) The Author(s) 2021

\begin{abstract}
Cadmium $(\mathrm{Cd})$, a toxic heavy metal, is harmful to plants and human health. Glutathione (GSH) could alleviate Cd toxicity of plant species, whereas its mechanism responsible for wheat remains poorly understood. Here, we found that exogenous GSH application significantly increased the fresh and dry weight, root elongation, chlorophyll contents, while decreased the contents of malondialdehyde (MDA) and GSH, and translocation factor of Cd compared with Cd treatment. Moreover, GSH application significantly increased activities of antioxidant enzymes and expression of related genes, which involved in GSH synthesis, especially in roots. In addition, we found that GSH application suppressed Cd-induced expression of metal transporter genes TaNramp1, TaNramp5, TaHMA2, TaHMA3, TaLCT1 and TaIRT2 in roots. Taken together, our results suggested that GSH could alleviate Cd toxicity in wheat by increasing GSH synthesis gene expression or suppressing Cd transporter genes expression, and further affecting Cd uptake and translocation in wheat plants.
\end{abstract}

Keywords Triticum aestivum L. · Cd · GSH · GSH synthesize genes · Cd transporter genes

Cadmium (Cd), a toxic heavy metal, is particularly dangerous and widely spread in the soil, and its accumulation would inhibit plant growth and development by disrupting the enzyme activities, hormone balance, protein synthesis, and key metabolic reactions (Rizwan et al. 2016a). It has reported that $\mathrm{Cd}$ accumulation in plants decreases crop production and quality, meanwhile, it also threatens human health (such as leading to cancer, cardiovascular, and osteoporosis disease) by food chain (Aziz et al. 2015). Therefore, it is imperative to block the Cd uptake and translocation from polluted soil to the edible parts of crops.

Plants have developed ranges of mechanisms to resist $\mathrm{Cd}$ toxicity, such as reducing $\mathrm{Cd}$ uptake and translocation, and

Ge-Zi Li and Shi-Juan Chen have contributed equally to this work.

Guo-Zhang Kang

guozhangkang@henau.edu.cn

1 National Engineering Research Center for Wheat, Henan Agricultural University, \#15 Longzihu College District, Zhengzhou 450046, Henan Province, People's Republic of China

2 National Key Laboratory of Wheat and Maize Crop Science, Henan Agricultural University, \#15 Longzihu College District, Zhengzhou 450046, Henan Province, People's Republic of China detoxifying/sequestering $\mathrm{Cd}$ in the subcellular organs (Liu et al. 2020; Jiang et al. 2020). Glutathione (GSH), a kind of non-enzymatic antioxidant from ascorbic acid-glutathione (ASA-GSH) system, is a low molecular weight thiol compound in plants, playing an important role in the different biological processes (Kuźniak et al. 2013), such as participating in the enzymatic reaction to reduce accumulation of reactive oxygen species and maintaining redox status homeostasis (Szalai et al. 2009). Furthermore, it also involves in phytochelatin synthesis (PCs), which could form complexes with the excessive heavy metals in the cytosol and then transported into vacuoles to alleviate toxicity of plants (Seth et al. 2012). Moreover, GSH participates in signal transduction of plant cells by controlling the gene expression in the processes of various abiotic stress, including heavy metals detoxification (Kim et al. 2017). However, the mechanism of GSH alleviated $\mathrm{Cd}$ tolerance in wheat still remains unclear.

$\mathrm{Cd}$ uptake, translocation, and detoxification in plants were carried out by a series of signal transduction pathways. For instance, several mediated Cd uptake and translocation genes, including Natural Resistance-Associated Macrophage Protein (NRAMP) family, Iron-Regulated Transporter 1 (IRT1) homologs, Low affinity Cation Transporter (LCT), and Heavy Metal ATPase (HMA), which were identified and characterized for the function mediated-Cd uptake or 
translocation in plants (Takahashi et al. 2012). On the other hand, plants also response to $\mathrm{Cd}$ stress by inducing the expression of defense genes, which contains antioxidants comprising ROS-removing enzyme gene ascorbate peroxidase (APX), glutathione reductase (GR), and non-enzymatic system genes GSH, glutathione S-transferase (GST), dehydroascorbate reductase (DHAR), and monodehydroascorbate reductase (MDHAR) in ASA-GSH system (Qin et al. 2018). However, the precise regulatory pathways influencing the above transporter or defense genes involved in Cd uptake and allocation are poorly clear.

Wheat, one of the globally important crops, has high and stable yield for humans and livestock, and thus, it is of great significance to the food security of China (Chen et al. 2019). Compared with other cereals, in Cd contaminated soils, wheat can accumulate more $\mathrm{Cd}$, mainly through the roots, which is transferred to aerial parts of the plant, and finally accumulated in the wheat grains, and the products of wheat are the major source of $\mathrm{Cd}$ intake by humans ( $\mathrm{Li}$ et al. 2020). Therefore, an important demand is that Cd minimization in wheat especially in Cd-contaminated soils. To date, however, there were no studies reported that GSH mediated$\mathrm{Cd}$ tolerance in wheat. To further study the effects of exogenous GSH on Cd tolerance in wheat, the characteristics of plant growth, the enzyme activities of GSH metabolism, the transcription levels of several genes involved in Cd uptake, detoxification and accumulation, and the uptake or accumulation of $\mathrm{Cd}$ elements, have been analyzed in this study. All results suggested that external GSH could alleviate $\mathrm{Cd}$ toxicity in wheat, and these results from our study will improve the understanding of $\mathrm{Cd}$ tolerance mechanisms in wheat and help develop strategies for alleviating $\mathrm{Cd}$ toxicity in wheat cultivation.

\section{Materials and Methods}

Wheat seeds (Triticum aestivum L. cv. Bainong 207) were surface-sterilized and germinated as previously described in our published literature (Li et al. 2013). Firstly, wheat seedlings grew in 1/2-strength Hoagland's solution $(\mathrm{pH}$ 6.5) for two weeks ( $\mathrm{Li}$ et al. 2017a, b). These two-week-old wheat seedlings were transferred to $0.5 \mathrm{mM} \mathrm{CaCl}_{2}$ solution ( $\mathrm{pH} 4.5$ ), which could reduced the competition of ions in Hoagland's solution and provided an acidic environment for increasing the activity of $\mathrm{Cd}^{2+}$ (Corrêa et al., 2011; Liu et al., 2018). Then, they were treated for $10 \mathrm{~d}$, which was selected according to the effect of different durations during Cd stress of wheat seedlings (Figure S1), with CK $(0.5 \mathrm{mM}$ $\left.\mathrm{CaCl}_{2}\right), \mathrm{Cd}\left(0.5 \mathrm{mM} \mathrm{CaCl}_{2}+50 \mu \mathrm{M} \mathrm{CdCl}_{2}\right), \mathrm{Cd}+\mathrm{GSH}$ $\left(0.5 \mathrm{mM} \mathrm{CaCl}_{2}+50 \mu \mathrm{M} \mathrm{CdCl}_{2}+20 \mu \mathrm{M} \mathrm{GSH}\right)$, and GSH $\left(0.5 \mathrm{mM} \mathrm{CaCl}_{2}+20 \mu \mathrm{M} \mathrm{GSH}\right)$. And the concentrations of $\mathrm{Cd}$ and GSH were performed as previously studies (Rizwan et al. 2016b; Li et al. 2017a, b; Qin et al. 2018). All these solutions were renewed every $48 \mathrm{~h}$.

The plant growth parameters, such as root length, fresh weight, dry weight, were measured after $10 \mathrm{~d}$ of treatment. The relative root elongation (RRE) and chlorophyll contents were calculated according to the method of Zheng et al. (2005) and Li et al. (2013). For root scanning, the whole roots were collected and scanned by flatbed scanner (Epson expression 16801.0 scanner, Japan). And the others samples were stored at $-80^{\circ} \mathrm{C}$.

Plant shoots and roots were dried and digested as previous study (Aprile et al. 2018), then, the shoot/root translocation factors of $\mathrm{Cd}$ were calculated according to the method of $\mathrm{Zhu}$ et al. (2020). Moreover, Cd contents in plant subcellular fractions, containing cell walls, organelles and cytosol, were also measured according to the method of Wu et al. (2005).

The malondialdehyde (MDA) and reduced glutathione (GSH) content assays according to our previous study ( $\mathrm{Li}$ et al. 2013). The activity of glutathione reductase coefficient (GR), glutathione S-transferase (GST) and glutathione peroxidase (APX) by using Assay Kits (Nanjing Jiancheng Institute of Biological Engineering, China).

Total RNA of wheat shoots and roots were extracted by using TransZol RNA Isolation Reagent (Tiangen, China) and determined the concentration. Then, $1 \mu \mathrm{g}$ of total RNA was prepared for reverse transcription by using ReverTra Ace qPCR RT Kit (Toyobo, Japan). qPCR was performed using AceQ $^{\mathrm{TM}}$ Universal SYBR $®$ qPCR Master Mix (Vazyme, China) as following reaction conditions: one cycle at $95^{\circ} \mathrm{C}$ for $10 \mathrm{~min}, 40$ cycles of amplification at $95^{\circ} \mathrm{C}$ for $10 \mathrm{~s}$, $58^{\circ} \mathrm{C}$ for $15 \mathrm{~s}$, and finally $72^{\circ} \mathrm{C}$ for $20 \mathrm{~s}$ in a QuantStudio 3 (Thermo, USA) system. The relative expression levels were calculated according to the method of $2^{-\Delta \Delta C T}$ (Schmittgen and Livak 2008). Wheat Glyceraldehyde 3-phosphate dehydrogenase (GAPDH) gene was used as an endogenous control gene in this study. All used primers were listed in Table S1.

Statistically analyses were performed by using the SPSS software (version 25.0), and the statistical assays were tested with LSD-test to evaluate significant differences between the treatments using a significance threshold of $p<0.05$. All the data in this study was calculated at least three biological replicates.

\section{Results and Discussion}

To determine the effect of GSH on Cd toxicity, wheat seedlings grew in different culture medium for 10 days. Compared with non-treated control (CK), the growth of wheat plants was inhibited, the color of leaves were displayed visible chlorosis, and the length of roots were inhibited in Cd treatment, while exogenous GSH significantly 
alleviated the above Cd toxicity effect (Figure S2). After application with exogenous GSH, the chlorophyll a and b contents restored to $61.6 \%$ and $65.9 \%$ of CK, respectively; and it was greater 2.35- and 2.42-folds than only treated with $\mathrm{Cd}$ (Table 1); the relative root elongation was inhibited $84.62 \%$ of CK, and it was lower 2.0 -folds than that of only Cd treatment (Table 1). Similarly, the fresh and dry biomass of plants, which were treated with $\mathrm{Cd}+\mathrm{GSH}$ treatment, decreased by $37.55 \%$ and $25.85 \%$ of CK, and they were 1.41 - and 1.17 -folds higher than that of $\mathrm{Cd}$ treatments (Table 1).
Supplement of GSH could modified metal toxicity by altering the rates of metal uptake or chelating metal ions in direct and indirect ways in different plants, including barley, rice, and maize (Chen et al. 2011; Cao et al. 2015; Li et al. 2017a, b). Similarly, in our study, application with exogenous GSH increased by $69.55 \%$ of Cd content in roots and decreased by $15.78 \%$ of Cd content in shoots, respectively (Fig. 1a). However, the translocation factor of $\mathrm{Cd}$ was decreased 0.49-fold in present with exogenous GSH compared with only Cd treatments (Fig. 1b). Further, the $\mathrm{Cd}$ contents in the fractions of cell walls (Fig. 1c), which

Table 1 Chlorophyll contents and biomass of wheat seedlings with or without Cd or GSH

\begin{tabular}{|c|c|c|c|c|c|}
\hline Treatments & $\begin{array}{l}\text { Chlorophyll a content } \\
\left(\mathrm{mg} \cdot \mathrm{g}^{-1}\right)\end{array}$ & $\begin{array}{l}\text { Chlorophyll b content } \\
\left(\mathrm{mg} \cdot \mathrm{g}^{-1}\right)\end{array}$ & $\operatorname{RRE}(\%)$ & Fresh weight $\left(\mathrm{g} \cdot\right.$ plant $\left.^{-1}\right)$ & Dry weight $\left(\mathrm{g} \cdot\right.$ plant $\left.^{-1}\right)$ \\
\hline $\mathrm{CK}$ & $1.18 \pm 0.002^{\mathrm{a}}$ & $0.44 \pm 0.002^{\mathrm{b}}$ & $100.0 \pm 0.455^{\mathrm{a}}$ & $0.77 \pm 0.087^{\mathrm{a}}$ & $0.079 \pm 0.01^{\mathrm{a}}$ \\
\hline GSH & $0.82 \pm 0.001^{\mathrm{b}}$ & $0.68 \pm 0.002^{\mathrm{a}}$ & $74.36 \pm 0.586^{\mathrm{b}}$ & $0.64 \pm 0.073^{\mathrm{b}}$ & $0.073 \pm 0.01^{\mathrm{b}}$ \\
\hline $\mathrm{Cd}$ & $0.31 \pm 0.002^{\mathrm{d}}$ & $0.12 \pm 0.001^{\mathrm{d}}$ & $7.700 \pm 0.208^{\mathrm{d}}$ & $0.37 \pm 0.041^{\mathrm{d}}$ & $0.050 \pm 0.01^{\mathrm{d}}$ \\
\hline $\mathrm{Cd}+\mathrm{GSH}$ & $0.73 \pm 0.001^{\mathrm{c}}$ & $0.29 \pm 0.002^{\mathrm{c}}$ & $15.38 \pm 0.830^{c}$ & $0.52 \pm 0.030^{c}$ & $0.058 \pm 0.01^{\mathrm{c}}$ \\
\hline
\end{tabular}

RRE, Relative root elongation; Data present means $\pm \mathrm{SE}(\mathrm{n}=3)$. The different letters represent significant difference at $p<0.05$
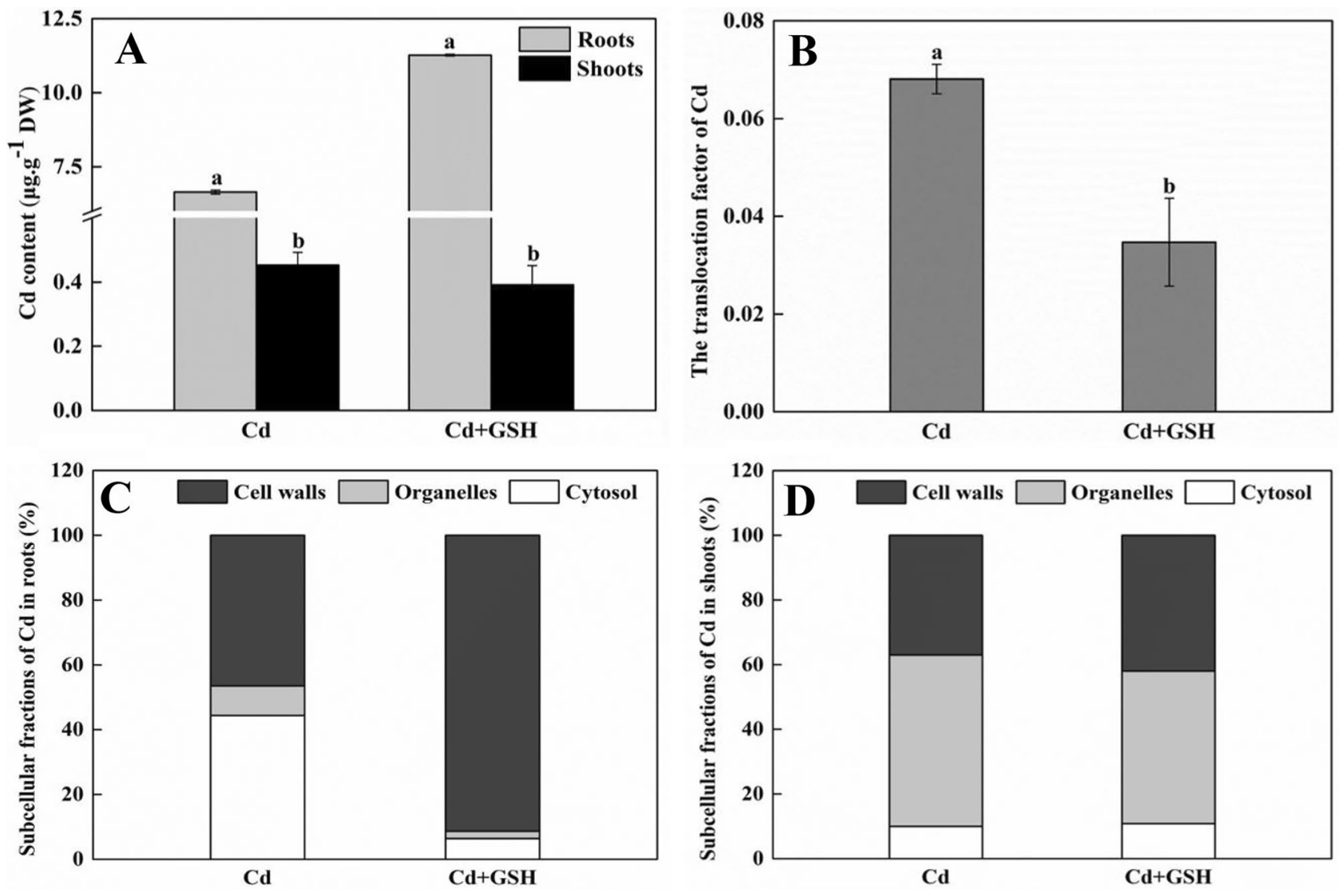

Fig. $1 \mathrm{Cd}$ content in wheat seedlings after Cd and GSH treatment for 10 days. a The content of $\mathrm{Cd}$ in roots and shoots of wheat seedlings; b The translocation factor of $\mathrm{Cd}$ from roots to shoots; $\mathbf{c}$ and $\mathbf{d}$ The

subcellular distribution of $\mathrm{Cd}$ in roots and shoots of wheat seedlings, respectively. Data present means $\pm \operatorname{SE}(\mathrm{n}=3)$. The different letters represent significant difference at $p<0.05$ 
are used for $\mathrm{Cd}$ sequestered and have a low toxicity, were significantly increased $260.5 \%$ in roots by GSH. While, in roots or shoots, the Cd levels were both decreased $55.3 \%$ or $34.1 \%$ and $19.8 \%$ or $73.4 \%$ by GSH in the organelles and cytosol (Fig. 1c and d), where the liable Cd is most toxic. These results indicated that exogenous GSH decreased rootto-shoot $\mathrm{Cd}$ translocation by sequestering more $\mathrm{Cd}$ in cell walls and regulated the subcellular compartmentalization of $\mathrm{Cd}$ in wheat roots.

To verify the role of exogenous GSH ameliorated oxidative stress under $\mathrm{Cd}$ stress, some indexes of oxidative stress, which contained the contents of MDA or GSH, and antioxidant enzymes (GST, APX, and GR), were determined in wheat plants. The results showed that exogenous GSH supplement significantly decreased 1.85 - or 1.65 -folds of MDA or reduced GSH contents compared with Cd treatment in roots, while they did not significantly changed in shoots (Table 2). Moreover, exogenous GSH supplement were significantly increased $32.4 \%$ and $12.9 \%$ of GST and GR activity compared with Cd treatment in roots (Table 3), respectively. And it significantly decreased the APX activity by $7.6 \%$ and $13.4 \%$ in roots and shoots, and GR activity by $21.8 \%$ in shoots compared with $\mathrm{Cd}$ treatment, respectively (Table 3). Compared with CK, GSH supplement had no effect on GST activity in shoots (Table 3). Similarly, application of exogenous GSH reduced contents of reactive oxidative species and MDA in maize, rice and tomato under Cd stress (Hasan et al. 2016; Li et al. 2017a, b; Zhou et al. 2017).

Transcription of defense gene expression provided more precise estimation than their enzyme activity in response to abiotic stresses (Chen et al. 2011; Kang et al. 2013).

Table 2 Contents of MDA and reduced GSH in wheat seedlings

\begin{tabular}{|c|c|c|c|c|}
\hline \multirow[t]{2}{*}{ Treatments } & \multicolumn{2}{|c|}{$\begin{array}{l}\text { MDA content }\left(\mu \mathrm{mol} \cdot \mathrm{g}^{-1}\right. \\
\mathrm{FW})\end{array}$} & \multicolumn{2}{|c|}{$\begin{array}{l}\text { Reduced GSH content } \\
\left(\mu \mathrm{mol} \cdot \mathrm{g}^{-1} \mathrm{FW}\right)\end{array}$} \\
\hline & Roots & Shoots & Roots & Shoots \\
\hline CK & $0.91 \pm 0.04^{\mathrm{c}}$ & $9.66 \pm 0.17^{\mathrm{d}}$ & $0.79 \pm 0.01^{\mathrm{d}}$ & $1.89 \pm 0.01^{\mathrm{a}}$ \\
\hline GSH & $0.93 \pm 0.07^{\mathrm{c}}$ & $10.89 \pm 0.30^{c}$ & $0.82 \pm 0.05^{\mathrm{c}}$ & $1.68 \pm 0.03^{\mathrm{c}}$ \\
\hline $\mathrm{Cd}$ & $2.16 \pm 0.17^{\mathrm{a}}$ & $22.88 \pm 0.80^{\mathrm{a}}$ & $3.02 \pm 0.06^{\mathrm{a}}$ & $1.73 \pm 0.01^{\mathrm{b}}$ \\
\hline $\mathrm{Cd}+\mathrm{GSH}$ & $1.17 \pm 0.01^{\mathrm{b}}$ & $19.21 \pm 1.19^{b}$ & $1.83 \pm 0.05^{\mathrm{b}}$ & $1.74 \pm 0.04^{b}$ \\
\hline
\end{tabular}

Therefore, the expression levels of four GSH synthesis genes were determined to investigate the molecular mechanism of GSH regulating Cd tolerance in wheat plants. Compared with CK, the expression levels of $G S H, G S T, G R$ and $A P X$ were significantly induced 1.04, 2.26, 5.94, 2.48-folds in roots (Fig. 2) or 1.83, 3.68, 2.20, 1.25-folds in shoots (Figure S3) under Cd treatment, respectively. Exogenous GSH application were further enhanced the expression levels of GSH (3.74-fold), GST (6.19-fold), GR (2.66-fold) in roots (Fig. 2a-c) or $A P X(1.79$-fold) in shoots (Figure S3D), while significantly decreased the expression levels of $G S H$ (46.3\%), GST (19.8\%), GR (79.9\%) in shoots (Figure S3B, $3 \mathrm{D}$ and $3 \mathrm{~F}$ ), compared with Cd treatment. This suggested that exogenous GSH could differentially regulated the expression profiles of these genes which might induced the changes of GSH content under Cd stress.

Regulation and manipulation of metal transporters is an important mechanism of alleviating heavy metal toxicity in plants (Ueno et al. 2010; Liu et al. 2013; Adrees et al. 2015). Such as the expression levels of OsNrampl, OsNramp5, OsHMA2 and OsHMA3, which were increased in rice roots exposure to $\mathrm{Cd}$ stress (Chen et al. 2019). And Yang et al. (2019) found Lanthanum reduced Cd accumulation in wheat by down-regulation the expression levels of TaNramp 5 and TaHMA2. Consistent with these, the expression levels of these $\mathrm{Cd}$ transporters were elevated in wheat plants to further understand the molecular mechanism of how GSH regulates the absorption, translocation, and allocation of $\mathrm{Cd}$ in wheat plants. The results showed that the expression levels of TaNramp1, TaNramp5, TaHMA2, TaHMA3, TaLCT1, and TaIRT2 were greatly induced 13.2-, 17.2-, 16.5-, 11.6-, 10.8- and 1.4-folds by $\mathrm{Cd}$ stress in roots compared with CK, respectively (Fig. 3). However, their transcriptions were significantly decreased 2.0- to 30.0-folds by exogenous GSH in roots (Fig. 3). Similarly, in shoots, except to TaIRT2 and TaHMA3, the expression levels of TaNramp1, TaNramp5, TaHMA2 and TaLCT1 were separately induced 1.6-, 2.8-, 4.9- and 1.3folds by Cd stress. And the exogenous GSH application was significantly decreased transcription of these genes (3.1-folds of TaNramp1, 1.2-folds of TaNramp5, 3.3-folds of TaHMA2, and 4.0-folds of TaLCT1) (Figure S4). It is interestingly that the only supplement of exogenous GSH
Table 3 Activity of antioxidant enzymes in wheat seedlings

\begin{tabular}{|c|c|c|c|c|c|c|}
\hline \multirow[t]{2}{*}{ Treatments } & \multicolumn{2}{|c|}{$\begin{array}{l}\text { GST activity }\left(\mu \mathrm{mol} \cdot \mathrm{mg}^{-1}\right. \\
\left.\text { protein } \mathrm{min}^{-1}\right)\end{array}$} & \multicolumn{2}{|c|}{$\begin{array}{l}\text { APX activity }\left(\mu \mathrm{mol} \cdot \mathrm{mg}^{-1}\right. \\
\left.\text { protein } \mathrm{min}^{-1}\right)\end{array}$} & \multicolumn{2}{|c|}{$\begin{array}{l}\text { GR activity }\left(\mu \mathrm{mol} \cdot \mathrm{mg}^{-1}\right. \\
\left.\text { protein } \min ^{-1}\right)\end{array}$} \\
\hline & Roots & Shoots & Roots & Shoots & Roots & Shoots \\
\hline CK & $133.78 \pm 9.6^{c}$ & $45.15 \pm 1.2^{\mathrm{a}}$ & $122.66 \pm 4.4^{\mathrm{c}}$ & $41.57 \pm 0.9^{c}$ & $0.54 \pm 0.0^{\mathrm{d}}$ & $1.17 \pm 0.1^{\mathrm{a}}$ \\
\hline GSH & $149.11 \pm 2.9^{c}$ & $38.51 \pm 2.0^{\mathrm{b}}$ & $123.76 \pm 2.3^{\mathrm{c}}$ & $45.55 \pm 0.7^{\mathrm{b}}$ & $0.90 \pm 0.1^{\mathrm{c}}$ & $1.02 \pm 0.0^{\mathrm{b}}$ \\
\hline $\mathrm{Cd}$ & $170.40 \pm 5.5^{\mathrm{b}}$ & $46.78 \pm 1.9^{\mathrm{a}}$ & $211.06 \pm 3.7^{\mathrm{a}}$ & $53.38 \pm 1.1^{\mathrm{a}}$ & $1.15 \pm 0.0^{\mathrm{b}}$ & $1.10 \pm 0.0^{\mathrm{a}}$ \\
\hline $\mathrm{Cd}+\mathrm{GSH}$ & $225.53 \pm 5.6^{\mathrm{a}}$ & $49.29 \pm 2.3^{\mathrm{a}}$ & $195.02 \pm 1.7^{b}$ & $46.24 \pm 0.6^{\mathrm{b}}$ & $1.30 \pm 0.0^{\mathrm{a}}$ & $0.86 \pm 0.0^{\mathrm{c}}$ \\
\hline
\end{tabular}



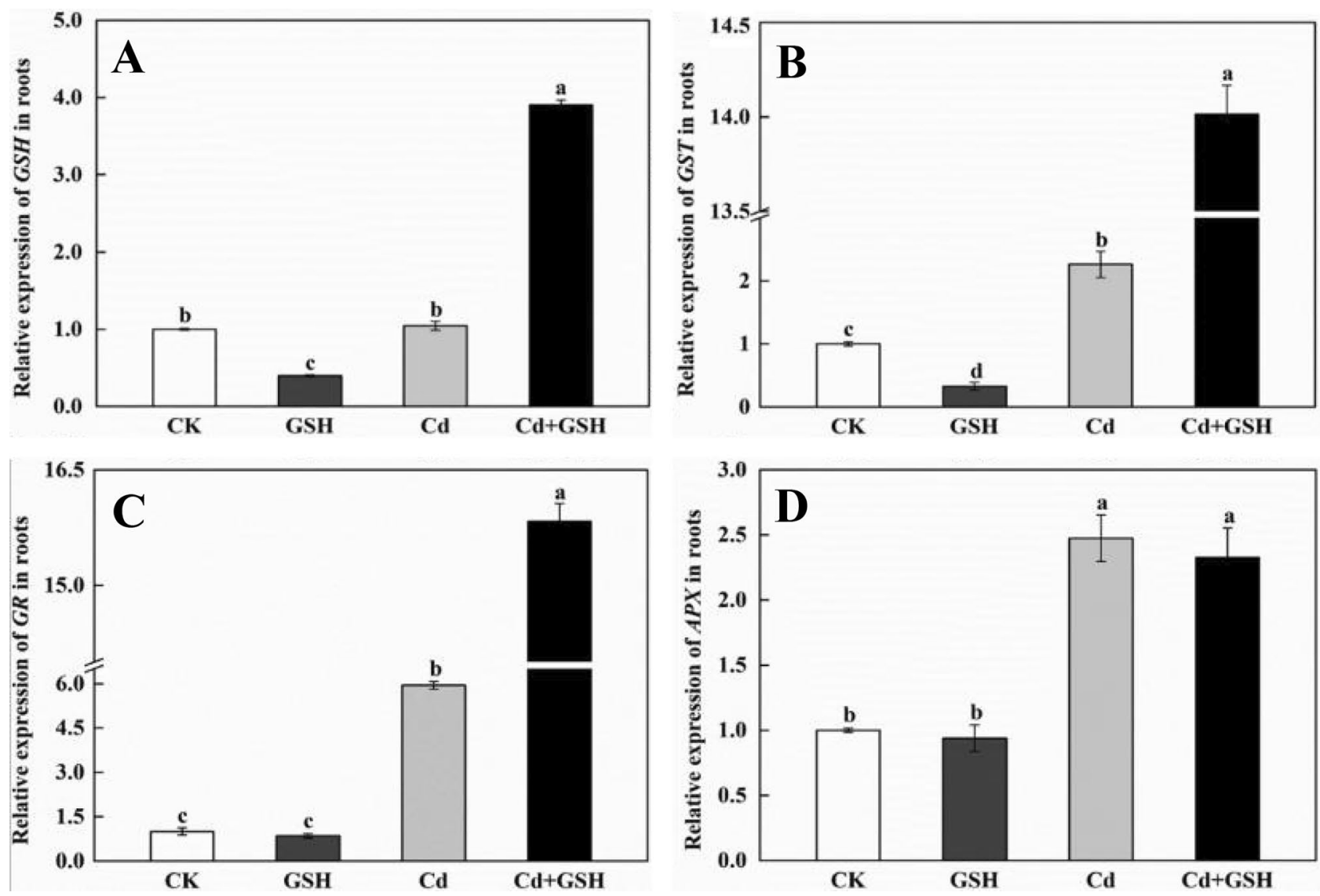

Fig. 2 Relative expression levels of genes in ASA-GSH cycles after $\mathrm{Cd}$ and GSH treatment for 10 days. The expression levels of $G S H$ (a), $G S T$ (b), GR (c), and APX (d) in roots of wheat seedlings; Data pre-

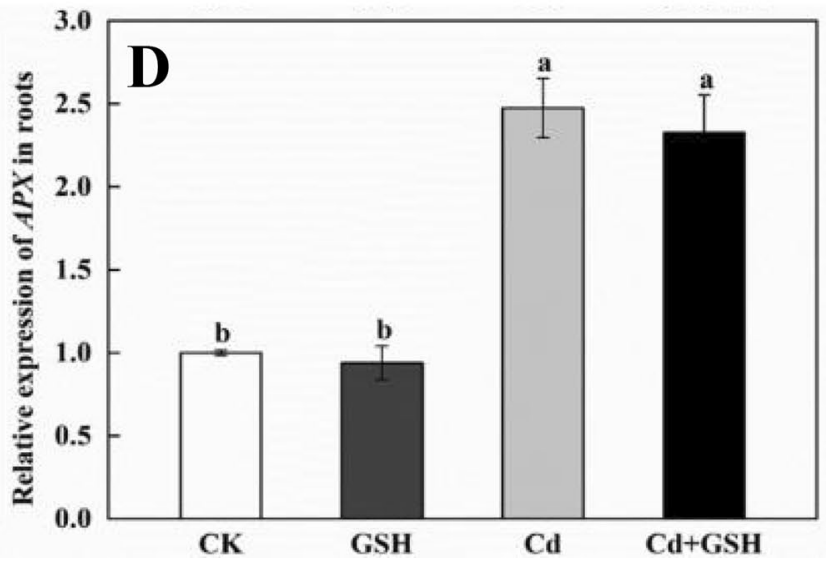

sent means \pm SE $(n=3)$. The different letters represent significant difference at $p<0.05$

inhibited (75\%-95\%) the transcription of these transporter genes in roots (Fig. 3), while induced 1.19- to 5.92-folds in shoots (Figure S4). These results were consisted with previous study (Kim et al. 2014; Clemens and Ma 2016; Chen et al. 2019). These results demonstrated that exogenous GSH reversed the Cd enhanced expression of transporter genes responsible for $\mathrm{Cd}$ uptake and translocation to alleviate $\mathrm{Cd}$ toxicity in wheat plants, especially in roots.

In conclusion, adding GSH significantly alleviates the inhibition of growth, reduces lipid peroxidation, and effectively protects wheat seedlings from $\mathrm{Cd}$ stress damage. This enhanced tolerance could be relevant to the increased

transcription of the GSH cycle-related genes and increased GSH content and biosynthesis, and decreased the transcription of $\mathrm{Cd}$ transporter genes. Our results contribute to elucidation of the effect of GSH on the plant response to $\mathrm{Cd}$ stress.

Supplementary Information The online version contains supplementary material available at https://doi.org/10.1007/s00128-021-03283-8.

Acknowledgements The work was financially supported by the National Natural Science Foundation of China (31701345 and U1704110). 

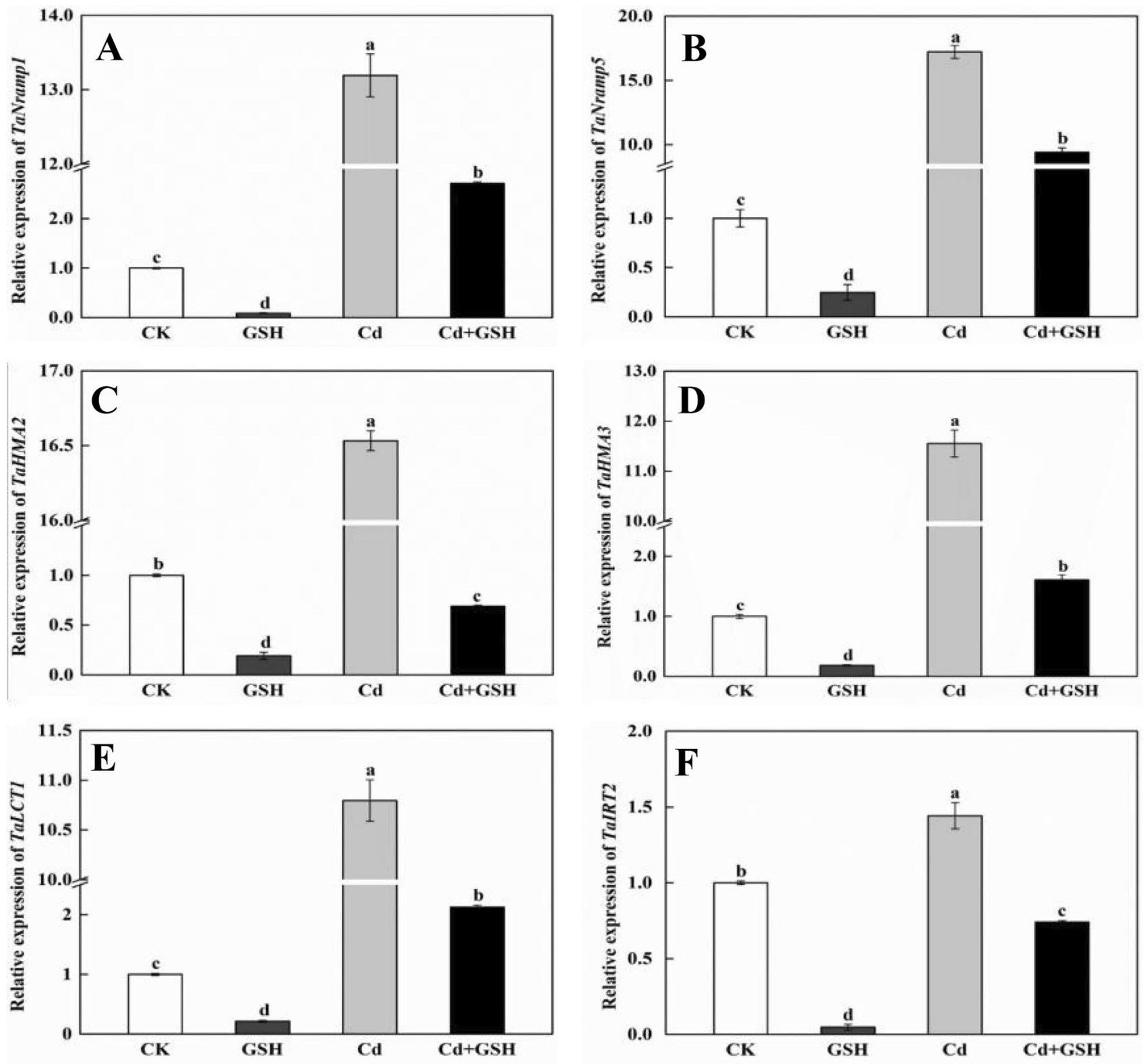

Fig. 3 Relative expression levels of Cd transporter genes in roots of wheat seedlings. The expression levels of TaNramp1 (a), TaNramp5 (b), TaHMA2 (c), TaHAM3 (d), TaLCT1 (e), and TaIRT2 (f) genes.

Data present means $\pm S E(n=3)$. The different letters represent significant difference at $p<0.05$

Open Access This article is licensed under a Creative Commons Attribution 4.0 International License, which permits use, sharing, adaptation, distribution and reproduction in any medium or format, as long as you give appropriate credit to the original author(s) and the source, provide a link to the Creative Commons licence, and indicate if changes were made. The images or other third party material in this article are included in the article's Creative Commons licence, unless indicated otherwise in a credit line to the material. If material is not included in the article's Creative Commons licence and your intended use is not permitted by statutory regulation or exceeds the permitted use, you will need to obtain permission directly from the copyright holder. To view a copy of this licence, visit http://creativecommons.org/licenses/by/4.0/.

\section{References}

Adrees M, Ali S, Rizwan M et al (2015) Mechanisms of silicon-mediated alleviation of heavy metal toxicity in plants: a review. Ecotoxicol Environ Safe 119:186-197

Aprile A, Sabella E, Vergine M et al (2018) Activation of a gene network in durum wheat roots exposed to cadmium. BMC Plant Biol 18:238

Aziz R, Rafiq MT, Li TQ et al (2015) Uptake of cadmium by rice grown on contaminated soils and its bioavailability/toxicity in human cell lines (Caco-2/HL-7702). J Agric Food Chem 63:3599-3608

Cao FB, Cai Y, Liu L et al (2015) Differences in photosynthesis, yield and grain cadmium accumulation as affected by exogenous 
cadmium and glutathione in the two rice genotypes. Plant Growth Regul 75:715-723

Chen SG, Liu ZM, Cui JX et al (2011) Alleviation of chilling-induced oxidative damage by salicylic acid pretreatment and related gene expression in eggplant seedlings. Plant Growth Regul 65:101-108

Chen DM, Chen DQ, Xue RR et al (2019) Effects of boron, silicon and their interactions on cadmium accumulation and toxicity in rice plants. J Hazard Mater 367:447-455

Clemens S, Ma JF (2016) Toxic heavy metal and metalloid accumulation in crop plants and foods. Annu Rev Plant Biol 67:489-512

Corrêa PC, Botelho FM, Oliveira GHH et al (2011) Mathematical modeling of the drying process of corn ears. Acta Sci Agron 33:575-581

Hasan MK, Liu C, Wang F et al (2016) Glutathione-mediated regulation of nitric oxide, S-nitrosothiol and redox homeostasis confers cadmium tolerance by inducing transcription factors and stress response genes in tomato. Chemosphere 161:536-545

Jiang M, Jiang J, Li S et al (2020) Glutamate alleviates cadmium toxicity in rice via suppressing cadmium uptake and translocation. $\mathrm{J}$ Hazard Mater 384:121319

Kang GZ, Li GZ, Liu GQ et al (2013) Exogenous salicylic acid enhances wheat drought tolerance by influence on the expression of genes related to ascorbate-glutathione cycle. Biol Plant 57:718-724

Kim YH, Khan AL, Kim DH et al (2014) Silicon mitigates heavy metal stress by regulating P-type heavy metal ATPases, Oryza sativa low silicon genes, and endogenous phytohormones. BMC Plant Biol 14:1-13

Kim YO, Bae HJ, Cho E, Kang H (2017) Exogenous glutathione enhances mercury tolerance by inhibiting mercury entry into plant cells. Front Plant Sci 8:683-692

Kuźniak E, Kaźmierczak A, Wielanek M et al (2013) Involvement of salicylic acid, glutathione and protein S-thiolation in plant cell death-mediated defence response of Mesembryanthemum crystallinum against Botrytis cinerea. Plant Physiol Biochem 63:30-38

Li GZ, Peng XQ, Wei LT et al (2013) Salicylic acid increases the contents of glutathione and ascorbate and temporally regulates the related gene expression in salt-stressed wheat seedlings. Gene 529:321-325

Li M, Hao PF, Cao FB (2017) Glutathione-induced alleviation of cadmium toxicity in Zea mays. Plant Physiol Biochem 119:240249

Li GZ, Wu YF, Liu GY et al (2017a) Large-scale proteomics combined with transgenic experiments demonstrates an important role of jasmonic acid in potassium deficiency response in wheat and rice. Mol Cell Proteomics 16:1889-1905

Li LP, Zhang YQ, Ippolito JA et al (2020) Cadmium foliar application affects wheat $\mathrm{Cd}, \mathrm{Cu} . \mathrm{Pb}$ and $\mathrm{Zn}$ accumulation. Environ Pollut 262:114329

Liu J, Ma J, He CW (2013) Inhibition of cadmium ion uptake in rice (Oryza sativa) cells by a wall bound form of silicon. New Phytol 200:691-699
Liu W, Xu F, Lv T et al (2018) Spatial responses of antioxidative system to aluminum stress in roots of wheat (Triticum aestivum L.) plants. Sci Total Environ 627:462-469

Liu XX, Yin L, Deng XP et al (2020) Combined application of silicon and nitric oxide jointly alleviated cadmium accumulation and toxicity in maize. J Hazard Mater 395:122679

Qin SY, Liu HE, Nie ZJ et al (2018) AsA-GSH cycle and antioxidant enzymes play important roles in Cd tolerance of wheat. Environ Contam Toxicol 101:684-690

Rizwan M, Ali S, Abbas T et al (2016a) Cadmium minimization in wheat: A critical review. Ecotoxicol Environ Saf 130:43-53

Rizwan M, Meunier JD, Davidian JC et al (2016b) Silicon alleviates Cd stress of wheat seedlings (Triticum turgidum L. cv. Claudio) grown in hydroponics. Environ Sci Pollut Res 23:1414-1427

Schmittgen TD, Livak KJ (2008) Analyzing real-time PCR data by the comparative C (T) method. Nat Protoc 3:1101-1108

Seth CS, Remans T, Keunen E et al (2012) Phytoextraction of toxic metals: a central role for glutathione. Plant Cell Environ 35:334-346

Szalai G, Kelloes T, Galiba G, Kocsy G (2009) Glutathione as an antioxidant and regulatory molecule in plants under abiotic stress conditions. J Plant Growth Regul 28:66-80

Takahashi R, Ishimaru Y, Shimo H et al (2012) The OsHMA2 transporter is involved in root-to-shoot translocation of $\mathrm{Zn}$ and $\mathrm{Cd}$ in rice. Plant Cell Environ 35:1948-1957

Ueno D, Yamaji N, Kono I et al (2010) Gene limiting cadmium accumulation in rice. Proc Natl Acad Sci USA 107:16500-16505

Wu FB, Dong J, Qian QQ, Zhang GP (2005) Subcellular distribution and chemical form of $\mathrm{Cd}$ and $\mathrm{Cd}-\mathrm{Zn}$ interaction in different barley genotypes. Chemosphere 60:1437-1446

Yang H, Xu ZR, Liu RX, Xiong ZT (2019) Lanthanum reduces the cadmium accumulation by suppressing expression of transporter genes involved in cadmium uptake and translocation in wheat. Plant Soil 441:235-252

Zheng SJ, Yang JL, He YF et al (2005) Immobilization of aluminum with phosphorus in roots is associated with high aluminum resistance in buckwheat. Plant Physiol 138:297-303

Zhou Y, Wen ZL, Zhang JW et al (2017) Exogenous glutathione alleviates salt-induced oxidative stress in tomato seedlings by regulating glutathione metabolism, redox status, and the antioxidant system. Sci Hortic 220:90-101

Zhu YX, Du WX, Fang XZ et al (2020) Knockdown of BTS may provide a new strategy to improve cadmium-phytoremediation efficiency by improving iron status in plants. J Hazard Mater $384: 121473$

Publisher's Note Springer Nature remains neutral with regard to jurisdictional claims in published maps and institutional affiliations. 